\title{
FORMAL DECENTRALIZATION OF LOCAL GOVERNANCE IN ALBANIA
}

\author{
Roland Lami ${ }^{1}$
}

\begin{abstract}
This article presents an argument on the regional effects of migration on Albanian administrativeterritorial reform and its consolidation. Many researchers of local politics support the thesis that an important demographic change is accompanied by a change related to the quality of service at local governance level. Compare to the Western and Eastern European countries, only in the early 1960s, Albania witnessed the introduction of the first regional and urban strategies. The strategy was used to limit the expansion of large towns and to encourage the development of small and medium-sized towns. Furthermore, there are a limited number of case studies based on migration data at regional level. This is why territorial reforms should often reflect ongoing demographic changes to minimize the effects caused by overpopulation, or significant reduction of the number of population in a local unit, with respect to quality of service offered to the citizens. We discuss the research question of "how will the demographic development, i.e. natural development of population as well as internal migration, affect different types of Albanian regions?" as well as "what is the impact of demographic movements on the quality of local governance?”

Based on the interpretation of some regional units, i.e. Tirana, Durres, and Fier, it is confirmed that the demographic movements in the last twenty years in Albania have brought about some changes. In some local units, the number of inhabitants is significantly reduced, while some other local units are overpopulated. This new reality leads to implications in economic, social and cultural aspects; and most importantly, we noticed an increasing dependency of local government on the central government. We further claim that local and regional authorities must participate in accordance with the "partnership" principle. Under these conditions, it is necessary to plan a new territorial division.
\end{abstract}

UDC Classification: 617.7, DOI: http://dx.doi.org/10.12955/cbup.v2.466

Keywords: decentralization, territorial reform, demographic development, local government, central government

\section{Introduction}

Albania has traditionally been a highly centralized state and made its the transition to democracy in 1991, without ever having experienced any significant form of local democratic government. Until its independence in 1912, the country was part of the Ottoman Empire, which was not encouraging decentralization or local autonomy. Similarly, during the period of the Zog Monarchy (1925 to 1939) and the Italian occupation (1939 to 1943), the local government was non-existent. After the Second World War, the communist regime made a determined effort to consolidate national independence by emphasizing the centralization of the state. The Albanian communist regime was one of the most authoritative among the socialist countries; local administration was a mean by which the central government and the Albanian Party of Labour controlled civil society. Local government was administered by People's Councils who administered the affairs of the district (rreth), the city (qytet), the locality (lokalitet), and the village (fshat). In 1992, an important issue of the Democratic Party government program was the reorganization of the local government. Law No. 7570 (1992) and Law No. 7572 (1992) on "The Organization and Functioning of Local Governments," as well as Law No. 7573 (1992) "On the elections of local government units" established decentralization as one of the basic goals and principles of local governance in Albania.

In 2000, a new administrative division was approved in Albania, with Law no. 8652 (dated July $31^{\text {st }}$, 2000) "on the organization and functioning of local governance." This law included no change from the previous division; the administrative territory of the Republic of Albania again composed of 65 municipalities, 308 communes, and 12 districts. Despite the fact that this law is considered very valuable, even today, from the standpoint of guaranteeing the competencies local government should

\footnotetext{
${ }^{1}$ Roland Lami, European University of Tirana, Albania, roland.lami@uet.edu.al
} 
exercise, since it is based on the best models of European countries; yet, the law fails to be enforced due to the lack of human and financial resources. Much of the debate on territorial reform in Albania has focused on the least populous units, wherein the most apparent weaknesses may be found in service provision and revenue collection. However, taking into account population density and geographical accessibility, mergers would lead to excessive distances between remote settlements and the administrative center bringing a challenge to local authorities. The relationship between the quality of local democracy and the size of local authorities is complex because, as Ericsson, Rudebeck, Sundström, \& Young (2012) noted, it is doubtful how much value should be placed on the government being close to the people when government is unable to perform many of its assigned tasks. Economic and institutional qualifications for the territorial division and consolidation pose challenges in Albania due to its citizens’ perceptions and demographic profile.

Although the population of communes and municipalities in Albania is comparable to the first-tier local authority areas of its close neighborhoods, some of the functions allotted to the local level in Albania are missing the intermediate tiers of the government. The experience of other European countries illustrates the scope for variety in the size and configuration of local government. In Albania, first-tier local authorities tend to cover the relatively large share of the population living in principal cities, especially the region of Tirana City.

According to Miller (2002), local government and decentralization are concepts, which are very closely inter-related but not synonymous; they do not always bear the same relationship to each other. In other words, while local government can be said to always represent some form of decentralization, decentralization does not always have to take the form of some type of local government. Additionally, different models of local government may represent different forms of decentralization. Davey (2011) pointed out that local Government is often portrayed as representing the highest form of decentralization, i.e. the devolution model. However, it is not always the same scenario. In the case of Albania, where most of local governments in the region operate as agents of central government, there is a limited scope for locally influenced decision-making, and for being very strongly controlled from the center-with respect to finance, staffing and exercise of their legal powers (Tony, 2010).

According to Stoker \& John (2009) and Harriss, Stokke, \& Törnquist (2004), the demographic component is closely related to local governance. In this context, an effective utilization of demographic data takes a specific role in terms of developing local policies to be adopted by the local governance (Grindle, 2007). In those local units, wherein the increase or reduction of the population is fast, there is a need to formulate effective policies aimed at addressing the problems that produce such dynamics. An efficient use of the demographic data is instrumental to the appropriate operation of the decentralization process. But, this is not happening in Albanian political reality. INSTAT census (2012) pointed out that, with regard to Albania's demographic future, the expected shrinking population in working age will lead to stagnation and, subsequently, reduction of total employment. It is, therefore, acknowledged that there is a need for interference in undertaking territorial reform. The citizens and communities are the final beneficiaries of the reform. They will enjoy more and better public services provided by the local government entities. Larger local government units will have more competencies, capacities, and funds to serve citizens more efficiently with services that meet the EU standards.

\section{Methodology}

The methodology used in this paper is closely related to the interpretation of the data obtained from secondary sources. These sources are the basis of theoretical material that we have received over the 
years of academic studies, as well as information collected from scientific journals, national and international institutions, Internet, etc.

\section{Local knowledge approach: In defense of fragmentation}

Migratory movements from the mountainous areas to the lowlands in the Western region of the country, during the last 13 years, have led to an overpopulation of some local units, but to a reduction of the population to some others, thus creating a demographic reality, which does not meet the criteria of administrative division of local government (AIIS, 2007). Therefore, $57 \%$ of local government units in Albania have less than 100 residents per square meter and about $28 \%$ of them have a density from 101 to 300 residents per square meter.

The administrative territorial reform leads to the consolidation of small local government units into larger and more efficient units that are capable of providing greater access, and delivering high quality and adequate public services to their citizens and communities. Currently, Albania has 12 regions (qarqe), 309 communes, and 65 municipalities. Today in Albania, the situations are as follows: 10 communes are populated with less than 1,000 inhabitants; 77 communes have up to 3,000 inhabitants; 65 communes have up to 5,000 inhabitants; 102 communes have between 5,000 and 10,000 inhabitants; 52 communes have between 10,000 and 20,000 inhabitants; and, 5 communes have over 20,000 inhabitants (Ericsson, Rudebeck, Sundström, \& Young, 2012). Referring to the data from the Census conducted in 2011 (INSTAT, 2011), it can be observed that the commune with the lowest number of population is Shosh Commune, in Shkodra, with 304 inhabitants; the commune with the highest number of residents is Kashar Commune, in Tirana, with 43,508 inhabitants. Regarding the municipalities, Tirana (at the center of Albania) is the largest municipality, with 401,100 inhabitants; Leskovik Municipality (in Southeastern part of Albania) is the smallest municipality, with 1,525 inhabitants, or 270 times less than those of Tirana (INSTAT, 2011). Figure 1 shows the national migration and population trends in Albania.

\begin{tabular}{|l|l|}
\hline Figure 1: Albania as a national "space of flows," migration and population trends \\
\hline Source: INSTAT (2011)
\end{tabular}

The darker areas in the map demonstrate areas with higher migration inflow recorded during the years between 2005 and 2010. The highlighted areas in the Northeast and Southeast of Albanian map demonstrate the least populated areas of Albania. This demographic situation reflects the level of income ensured by these units. Communes with 10,000 inhabitants have three times less income per capita compared to local units with over 10,000 inhabitants. For this reason, about 40 communes spend over $80 \%$ of their budget on salaries and provide almost no services to their citizens, while 230 
communes spend over $60 \%$ of their budget on salaries, significantly reducing the opportunities for investments (Ministry of Finance, 2013). In addition, central government allocates respective budgets for these local units in a very disproportionate manner. In 2012, the local government revenue was 14.6 billion ALL (140.2 million USD as of April 13, 2013), while spending was over 29.5 billion ALL (280.6 million USD as of April 13, 2013). This year, the revenue that local governments should gather is 9.8 billion ALL (95 million USD as of April 13, 2013), while its spending is about 28.6 billion ALL (270.7 million USD as of April 13, 2013). According to High State Control (2013), this financial reality is paradoxical, i.e. the income from the budget state is at $94.1 \%$ while only $5.9 \%$ are ensured by local government units. As a result, investments per inhabitant at district level are 229 ALL (2.2 USD as of April 13, 2013) per inhabitant. Furthermore, there are local units that ensure only one EUR per capita income.

Many countries in Europe have successfully implemented a similar Administrative-Territorial Reform in the last two decades. This includes Denmark, Sweden, Macedonia, Latvia, Poland, Estonia, and a few other countries. Furthermore, Albania is following a similar experience of its neighbor, Macedonia, which is divided into 84 opštini (municipalities). In 1996, Macedonia was organized into 123 opštini (municipalities) by a Law on Territorial Division. The Law on Territorial Organization passed by Parliament reorganized Macedonia into 84 municipalities.

As Ericsson et al. (2012) note: in most cases, the new municipalities are equal to one or several of the old ones. A target of between five and eight local authorities per region (depending on regional preferences and conditions), or approximately eight for the country as a whole, would constitute a bold step toward stronger political and administrative decentralization. The figure of approximately 90 local units for the country as a whole (or average population of approximately 35,000 inhabitants) is based, first of all, on our appreciation of what would be needed to make a meaningful difference to the capacity of the local authorities to fulfill their legal responsibilities.

In the design and implementation of territorial reforms, from Albania's national commitments, local knowledge and interests are yet to be taken into account. In the absence of such reforms, the local powers will be transferred back to central ministries or perhaps to strengthened regional authorities. This is evidently undesirable for local authorities, themselves, and from the perspective of Albania's stated ambitions for decentralization (Ericsson et al (2012)). However, a sufficient condition for effective decentralization, depends on a political will and increased financial means. On the other hand, at regional level, Wilson (2011) noted the formal consultation with local inhabitants and regional, municipal, and communal councils should be ready for the 2015 local elections in Albania.

Such a situation has brought about a mandatory financial dependence from the central government and has increased the dissatisfaction of citizens in relation to the services they receive from the local government (Ericsson, Rudebeck, Sundström, \& Young, 2012). Based on the above data, we notice only a de jure decentralization of local government units, because some of the local units do not possess the financial capacity to generate income and human capital to properly administer even the little revenue they have. Under these conditions, the need for survival forces local government to restrict the sphere of independence in order to ensure financial income from central government.

\section{Conclusion}

Albania is a small country, but with some geographical and topographical differences among its regions. The present number of 12 regions is a few too many for such a small country. A smaller number of larger regions, e.g. five to seven, would bring Albania closer in line with other European countries, enabling the regions to develop those functions, which are usually allocated to this level of territorial governance—socioeconomic development, as well as environmental matters. According to 
Ericsson, Rudebeck, Sundström, \& Young (2012), there is an urgent need to undertake a new administrative-territorial division based on a minimal number of population (15,000 residents in one municipality and 10,000 residents in one commune). Meeting this criterion would significantly reduce the actual number of local government units. This shall lead to the reduction of their administrative expenditures. At the same time, this change shall increase the opportunities to provide more income and shall decrease the degree of dependence of local units on the central government. The key tasks of the democratization process is to create a new system of genuine local and regional government rather than simple administration at these levels.

\section{References}

Albanian Institute for International Studies (2007). Rritja e Transparences ne Nivel Lokal [Transparency Increased at the Local Level]. Tirana: NED Publisher.

Albanian Institute of Statistics (INSTAT) (2011). 2011 Population and Housing Census in Albania: Preliminary Results. Albanian Institute of Statistics. Retrieved from https://unstats.un.org/unsd/demographic/sources/census/2010_phc/Albania/Albania.pdf

Davey, K. (2011). Local Government in Critical Times: Policies for Crisis, Recovery and a Sustainable Future. Strasbourg: Council of Europe. Retrieved from http://www.ccre.org/docs/Local_Government_in_critical_times.EN.pdf

Ericsson, E. L., Rudebeck, K., Sundström, B., \& Young, D. (2012). Territorial Reform in Albania. Study for the Albanian Association of Communes. Project Number 122210310. Tirana, Albania. Retrieved from http://www.shtetiweb.org/wpcontent/uploads/2013/10/121218-SKL-Albania-final-lores.pdf

Grindle, S. M. (2007). Decentralization, Democratization and the Promise of Good Governance. New Jersey: Princeton University Press.

Harriss, J., K. Stokke, \& Törnquist, O. (Eds.). (2004). Politicizing Democracy. Critical perspectives on the new local politics of democratization. Houndmills: Palgrave-Macmillan.

Levitas, T. (2010). Local Government Taxes, Fees and Charges in Albania: Current and Future Challenges. Study on behalf for the Association of Albanian Communes, SKL Publisher.

Miller, L. K. (2002), Advantages and Disadvantages of Local Government Decentralization. Retrieved from http://citeseerx.ist.psu.edu/viewdoc/download?doi=10.1.1.134.5990\&rep=rep1\&type=pdf

Ministry of Finance (2013). Economic and Fiscal Program 2012 - 2014. Country Report. Republic of Albania. Retrieved from http://www.mete.gov.al/doc/Programi_Ekonomik_dhe_Fiskal_2012_-_2014.pdf

Stoker, G., \& John, P. (2009). Design Experiments: Engaging Policy Makers in the Search for Evidence about What Works. Political Studies, 57(6), 356-373.

Wilson, D. (2011). Beyond Administrative Borders: IMC in Albania, In: Swianiewicz, P. (Ed.), Working Together: Intermunicipal Cooperation in Five Central European Countries (pp. 19-98). Retrieved from http://observgo.uquebec.ca/ observgo/fichiers/85195_GLR-3.pdf

World Bank (2004). Albania: Decentralization in Transition, Report No. 27885-ALB, February. Retrieved from http://siteresources.worldbank.org/INTALBANIA/Resources/DecentralizationInTransition1.pdf 